\title{
Identification of pheromone-binding proteins of the maize stem borer, Chilo partellus (Swinhoe, 1885) (Lepidoptera: Crambidae)
}

\author{
D. Pedda Kasim ${ }^{1}$, R. Srideepthi ${ }^{1}$, P. Suneetha ${ }^{2}$, M. S. R. Krishna ${ }^{1 *}$ and U. Lakshmisahitya ${ }^{1}$
}

\begin{abstract}
Pheromone-binding proteins (PBPs) play a significant role in olfaction and mating. The present work was designed to isolate, extract, and purify the pheromone-binding proteins from the antennae of male Chilo partellus (Swinhoe, 1885) (Lepidoptera: Crambidae). The pheromone-binding proteins extracted from the male antennae were found to be $770 \mu \mathrm{g}$ in $100 \mathrm{mg}$ of sample. Pheromone-binding protein molecular weight was determined as 17 kDa by SDS-PAGE analysis. Identified proteins were purified through gel extraction with a recovery percentage of proteins up to $95 \%$. Purified protein samples are analyzed on native PAGE gels. Relative mobility of proteins was determined as $0.574 \mathrm{~nm}$ in the densitometry analysis. These identified pheromone-binding proteins can be used for identification of novel pheromone compounds in in vitro studies. This study can be helpful in designing integrated pest management programs to control the maize stem borer by mass trapping of male moths.
\end{abstract}

Keywords: Chilo partellus, Pheromone-binding proteins, SDS-PAGE, Densitometry

\section{Background}

Chilo partellus (Swinhoe, 1885) (Lepidoptera: Crambidae) is a devastative pest, majorly hampering the production of several cereal crops, viz., maize, sorghum, sugarcane, and rice. It infests the crop at all stages and results with a yield loss from 26.7 to $80.4 \%$ in Indian maize (Manjunath and Mallapur 2017). There is no permanent solution to control this pest through plant breeding. Usage of chemicals results to negative impact on the environment. However, bio-control agents such as parasitoids, predators, and pathogens suppressed the population outgrowth of $C$. partellus to an extent, but their activity was not adequate to decline the pest populations below the financial damage level (Divya et al. 2010). Integrated pest management (IPM) is one of the best methods for control of the maize stem borer and obtaining the highest yield (Khan et al. 2015).

\footnotetext{
* Correspondence: msrkrishna_bt@kluniversity.in

${ }^{1}$ Department of Biotechnology, KL University, Green Fields, Vaddeswaram,

Guntur, AP 522502, India

Full list of author information is available at the end of the article
}

An insect detects hydrophobic volatile molecules (odorants) present in the environment by hydrophilic antennal lymph to the olfactory receptor by odorantbinding proteins (OBPs) (Garczynski et al. 2013), and thus, OBPs play important roles in the olfaction. OBPs are small, water-soluble, extracellular proteins that are located in the fluid surrounding the sensory dendrite and abundantly found in lymph of insect antennae and other sensory organs (De Biasio et al. 2015). They are reflected to be vital in insect olfactory perception at various levels but the exact mechanism is still unknown.

Pheromone-binding proteins (PBPs) represent a sub-class of insect odorant-binding proteins, particularly related in the detection of sex pheromones (Pelosi et al. 2006). The term pheromone was derived from a Greek word pherein which means to carry or transfer and hormone to excite or stimulate. Bombykol is the first identified pheromone released by female silkworms to attract its mating partner (Zhou et al. 2009). PBPs were found in the antennae of females and in sensilla of males which are not pheromone-sensitive (Callahan et al. 2000). Pheromones induce a change in 
the behavior of the receiving individual within the same species (Wyatt 2010). They act as carriers for antagonists and scavengers for pheromone components in female insects (Zhou et al. 2009).

Research is going on to understand the molecular mechanisms by unrevealing the role of OBPs and PBPs in olfactory perception. To address the damage caused by $C$. partellus through molecular level application in IPM programs, an initiative work to extract and purify the pheromone-binding proteins of male C. partellus antennae was carried out.

\section{Materials and methods \\ Sample collection}

Chilo partellus male moths were collected from the maize fields by using pheromone traps in the farmer fields in Vaddeswaram, Guntur, India.

\section{Sample protein preparation}

Male C. partellus moth antenna tissue $(100 \mathrm{mg})$ was taken and homogenized with the help of mortar and pestle using $500 \mu \mathrm{l}$ of $1 \mathrm{M}$ Tris buffer ( $\mathrm{pH}$ 7.5) containing $10 \%$ SDS and $0.02 \mathrm{M}$ EDTA. The homogenate was centrifuged at $14,000 \mathrm{rpm}$ for $12 \mathrm{~min}$ at $4{ }^{\circ} \mathrm{C}$. Supernatant fraction was carefully collected in fresh autoclaved tubes; the sample was stored at $-20{ }^{\circ} \mathrm{C}$ until further use. The protein was estimated according to standard protocol suggested by Lowry et al. (1951) using bovine serum albumin (BSA) as standard.

\section{Preparation of sample protein for SDS-PAGE}

A ratio of 1:1 protein sample and $1.0 \mathrm{M}$ Tris buffer (pH 6.8) containing 10\% SDS, $2 \% \beta$-mercaptoethanol, $10 \%$ glycerol, and $0.002 \%$ bromophenol blue was added and kept at $90{ }^{\circ} \mathrm{C}$ for 5 min (Kasim et al. 2015).

\section{Separation of PBPs by SDS-PAGE}

Sodium dodecyl sulfate polyacrylamide gel electrophoresis (SDS-PAGE) was used to determine the molecular weight distribution of insect proteins as described by Nagnan-Le et al. (1996). To study the SDSPAGE protein profile, one-dimensional SDS-PAGE ( $12 \%$ separating gel and $4 \%$ stacking gel) was carried out in a small vertical system. To $10 \mu \mathrm{g}$ of protein, $10 \mu \mathrm{l}$ of lamellae buffer (loading dye) was mixed and samples were incubated at $95{ }^{\circ} \mathrm{C}$ for $5 \mathrm{~min}$ in water bath and then immediately load the protein sample into the wells. The loading buffer containing bromophenol blue acts as a tracking dye. A medium range marker (NEX-GEN blue spray prestain protein ladder) was also loaded into the well for the determination of molecular weight through protein bands. The gel was run at constant voltage of $80 \mathrm{~V}$ for 3-4 h followed by staining with Coomassie brilliant blue R-250 overnight.
The relative mobility of protein bands was determined and the zymogram was constructed.

\section{Extraction and purification of proteins from SDS-PAGE}

After SDS-PAGE electrophoresis, proteins were extracted and purified according to Nagnan-Le et al. (1996). The visualized bands are removed from the gel using a surgical blade and washed using $2 \mathrm{ml}$ of $250 \mathrm{mM}$ Tris buffer/250 mM EDTA, $\mathrm{pH}$ of 7.4, thoroughly for three times then finally washed with autoclaved distilled water. The water was completely removed from the gel slices and homogenized with $1 \mathrm{ml}$ of Tris buffer ( $\mathrm{pH} 7.4$ ). The samples were subjected to sonication then centrifuged at 12,000 rpm for $10 \mathrm{~min}$ at $4{ }^{\circ} \mathrm{C}$. The protein sample was equilibrated with $20 \mathrm{mM}$ Tris buffer, $\mathrm{pH} 7.4$, containing $0.1 \%$ SDS. The partially purified protein aliquots were run in the native PAGE; it is used for the densitometric analysis and determination of the recovery percentage.

\section{Densitometry analysis}

To identify the universal expression pattern of existing protein spots on gel, densitometry analysis was employed. It is majorly used to measure protein expression levels and the intensities of specific bands by using an online software tool (Gelquant.NET). In this study, the relative amounts of protein were quantified by using a computational program from a TIFF image assisted with a commercial scanner. Relative mobility (Rf) of each stained band, its concentration, and area occupied by it with reference to total protein present in the lane can be calculated by gel perfect program explained by Bozzo and Retamal (1991). SDS-PAGE gels of purified proteins were digitized, and peak areas of both purified and crude protein bands were compared. The relative concentration of areas provides us the percentage recovery.

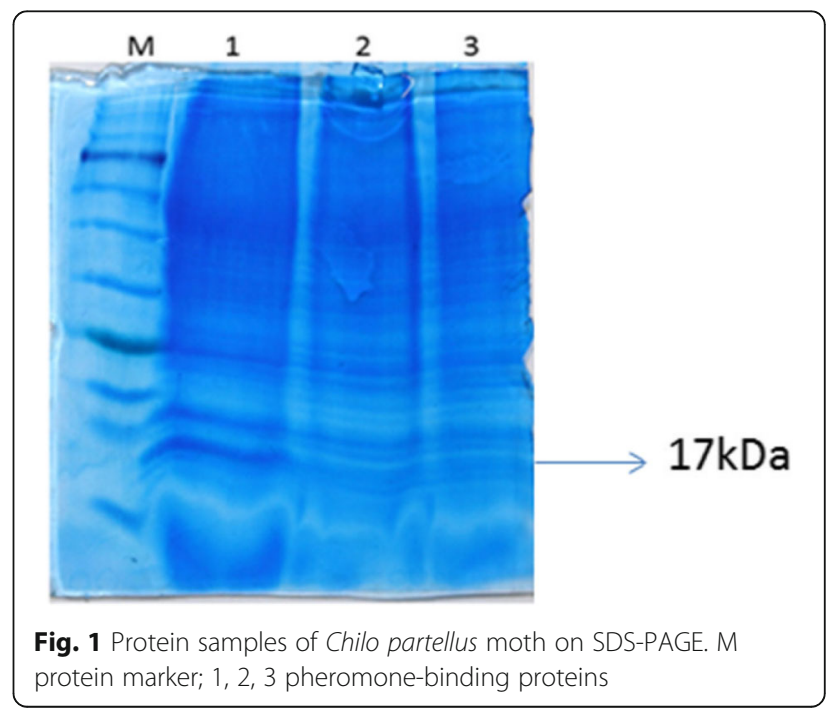




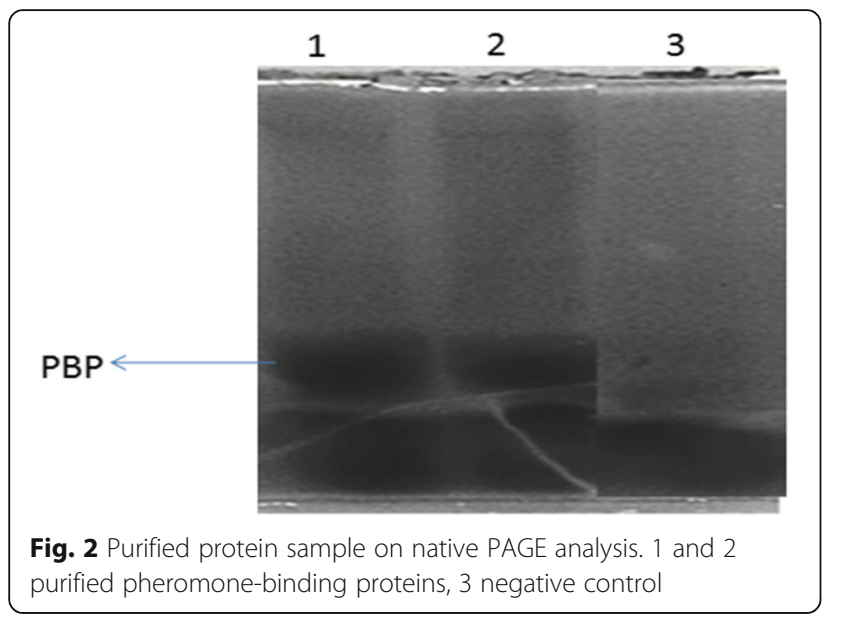

\section{Results and discussion}

\section{Separation of PBPs by SDS-PAGE}

Extracted proteins from the sensory organs were quantified by using Lowry's method and the protein concentration was found to be $0.77 \mu \mathrm{g} / \mathrm{mg}$. Molecular weight of the extracted proteins was determined using SDS-PAGE (12\% resolving gel and $4 \%$ stacking gel). Usually, molecular weight of PBP was of $17 \mathrm{kDa}$ and found to be the same in our results (de Santis et al. 2006) using a protein marker (NEX-GEN blue spray pre-stain protein ladder) (Fig. 1).

\section{Extraction and purification of proteins from SDS-PAGE}

The identified proteins were further purified through gel extraction and recovery of protein varied from 80 to 95\%. Purified samples were run on native PAGE gel with negative control (Fig. 2). Few samples are homogenized and purified using Tris buffer $(20 \mathrm{mM}, \mathrm{pH}$ 7.4) without SDS, while recovery percentage was observed to be slightly lower when compared to SDS. Our results illustrate that it was not critical to use a large quantity of starting material to achieve an adequate amount of purified protein either to improve an immunoassay or to characterize a protein chemically.

\section{Densitometry analysis}

Through densitometry analysis, the electrophoretic mobility was calculated, using molecular weights of proteins with reference to protein marker standards (Priya et al. 2013). In this analysis, the perfect gel picture on relative mobility of protein was observed to be $0.574 \mathrm{~nm}$ (Fig. 3a) and the band intensity was approximately 250 units as shown in (Fig. 3b).

Results of this study may serve as preliminary information to identify olfaction-based approaches which interfere with insect host location and mating behavior through a strategy called push-pull pest control. PBPs are the ideal targets for understanding the olfactory code of insects as well as for interfering with their communication system. These proteins are specifically expressed in the antennae of male moths. Insects survive by possessing a specialized sensory system to monitor various odors present in the environment. Thus, sense of smell often plays a crucial role for detecting food, mating partner, and choosing for oviposition site or even protecting themselves from predators and pathogens to fit among various existing ecological lifestyles (Cande et al. 2013). Considering the importance of PBPs of male moths, they play a vital role in the detection of sex pheromones. Leal (2013) stated that male moths detect sex pheromones with tuned odorant receptors, which confer specificity to peripheral odorant receptor neurons, with the assistance of other olfactory proteins.

\section{Conclusions}

In conclusion, the pheromone-binding protein receptors are present in the male and female antennae of $C$. partellus moth. Male-specific PBPs are important for sexual mating. In this study, PBPs were extracted and purified from the antenna tissue. Extracted PBPs can be used for further protein sequence analysis and molecular docking studies. These PBPs can be used in identification of novel pheromone compound screening, which can be used in integrated pest management for sustainable agriculture.

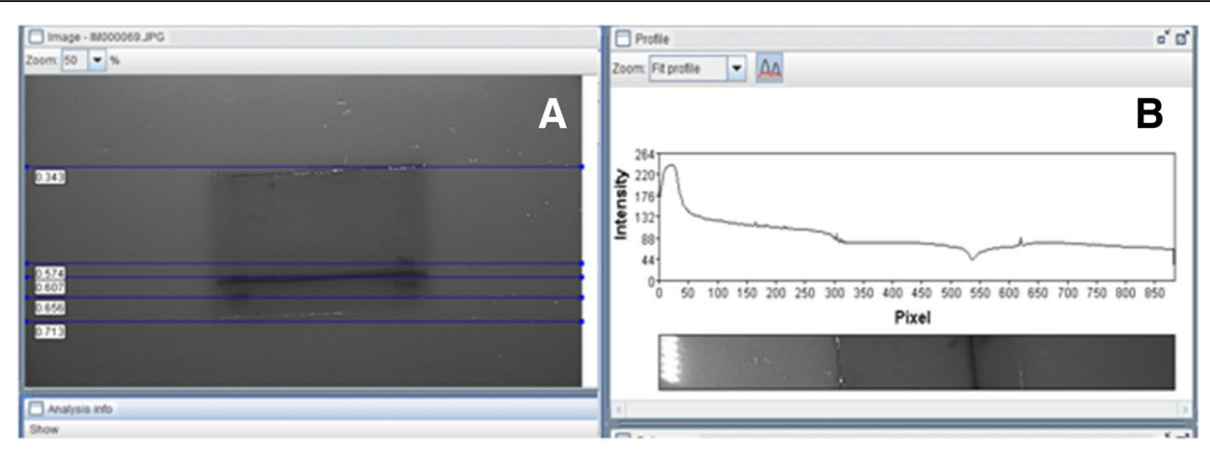

Fig. 3 Densitometry analysis of purified protein samples. a Rf value of protein sample. b Purified protein sample band intensity 


\section{Acknowledgements}

The authors are thankful to KL University for providing the lab facilities and Dr. K. Srinivasulu, Department of Biotechnology, for the constant support to carrying out this work.

\section{Authors' contributions}

DPK carried out the SDS-PAGE studies. RS participated in Native PAGE studies. PS participated in rearing of moths. MSRK conceived of the study and participated in design and coordination. UL performed densitometry analysis. All authors read and approved the final manuscript.

\section{Competing interests}

The authors declare that they have no competing interests.

\section{Publisher's Note}

Springer Nature remains neutral with regard to jurisdictional claims in published maps and institutional affiliations.

\section{Author details}

${ }^{1}$ Department of Biotechnology, KL University, Green Fields, Vaddeswaram, Guntur, AP 522502, India. 'Institute of Biotechnology, Prof. Jayashankar Telangana State Agricultural University, Hyderabad 500030, India.

Received: 10 July 2017 Accepted: 6 December 2017

Published online: 30 January 2018

\section{References}

Bozzo S, Retamal C (1991) Gel-perfect: geles unidimensionales. Unnuevo método densitométrico para computadores personales. Arch Biol Med Exp 24:181

Callahan FE, Vogt RG, Tucker ML, Dickens JC, Mattoo AK (2000) High level expression of "male specific" pheromone binding proteins (PBPs) in the antennae of female noctuiid moths. Insect Biochem Mol Biol 30:507-514

Cande J, Prudhomme B, Gompel N (2013) Smells like evolution: the role of chemoreceptor evolution in behavioral change. Curr Opin Neurobiol 23:152-158

De Biasio F, Riviello L, Bruno D, Grimaldi A, Congiu T, Sun YF, Falabella P (2015) Expression pattern analysis of odorant-binding proteins in the pea aphid Acyrthosiphon pisum. Insect Sci 22:220-234

Divya K, Marulasiddesha KN, Krupanidhi K, Sankar M (2010) Population dynamics of spotted stem borer, Chilo partellus (Swinhoe) and its interaction with natural enemies in sorghum. India J Sci Technol 3(1):70-74

Garczynski SF, Coates BS, Unruh TR, Schaeffer S, Jiwan D, Koepke T, Dhingra A (2013) Application of Cydia pomonella expressed sequence tags: identification and expression of three general odorant binding proteins in codling moth. Insect Sci 20:559-574

Kasim D, Suneetha P, Sahitya U, Srideepthi R, Krishna MSR (2015) Seed storage protein profiling and phylogenetic relationships of Capsicum annum L., cultivars using SDS-PAGE. Res J of Biotech 10(2):1-4

Khan IU, Nawaz M, Fazal S, Kamran S, Subhanullah (2015) Integrated pest management of maize stem borer, Chilo partellus (Swinhoe) in maize crop and its impact on yield. J Ento Zool Stu 3(5):470-472

Leal WS (2013) Odorant reception in insects: roles of receptors, binding proteins, and degrading enzymes. Annu Rev Entomol 58:373-391

Lowry OH, Rosebrough NJ, Farr AL, Randall RJ (1951) Protein measurement with the Folin phenol reagent. J Biol Chem 193:265

Manjunath C, Mallapur CP (2017) Assessment of crop loss and economic injury level of maize stem borer, Chilo partellus (Swinhoe). J. Ento. Zool. Stu. 5(4): 1530-1535

Nagnan-Le, M.P. Huet, J.C. Maibeche, M. Pernollet, J.C. and Descoins, C. 1996. Purification and characterization of multiple forms of odorant/pheromone binding proteins in the antennae of Mamestra brassicae (Noctuidae). Insect Biochem. Mol Biol, 26(1):59-67

Pelosi P, Zhou JJ, Ban LP, Calvello M (2006) Soluble proteins in insect chemical communication. Cell Mol Life Sci 63:1658-1676

Priya GL, Rameshkumar P, Ponmanickam P, Eswaran R, Sudarmani DNP, Rajagopal $\mathrm{T}$ (2013) Identification of volatile and protein profiles in the sting and mandibular glands of the worker honey bee (Apis cerana indica). Biochem Physiol 2:108

de Santis F, François M-C, Merlin C, Pelletier J, Maïbèche-Coisné M, Conti E, Emmanuelle, Jacquin-Joly (2006) Molecular cloning and in situ expression patterns of two new pheromone-binding proteins from the corn stem borer Sesamia nonagrioides. J Chem Ecol 32:1703-1717
Wyatt TD (2010) Pheromones and signature mixtures: defining species-wide signals and variable cues for identity in both invertebrates and vertebrates. J Comp Physiol A 196(10):685-700

Zhou JJ, Robertson G, He X, Dufour S, Hooper AM, Pickett JA, Keep NH, Field LM (2009) Characterization of Bombyx mori odorant-binding proteins reveals that a general odorant-binding protein discriminates between sex pheromone components. J Mol Biol 389:529-545

\section{Submit your manuscript to a SpringerOpen ${ }^{\circ}$ journal and benefit from:}

- Convenient online submission

- Rigorous peer review

- Open access: articles freely available online

- High visibility within the field

- Retaining the copyright to your article

Submit your next manuscript at springeropen.com 